Archived version from NCDOCKS Institutional Repository http://libres.uncg.edu/ir/asu/

\title{
Appalachľan
}

B O O N E, N O R T H C A R O L I N A

\section{Cultural Appropriation Of The Death Celebrations: The Case Of Halloween}

\author{
By: Pia A. Albinsson, Marco Wolf, G. David Shows, and Karen M. Hood
}

\begin{abstract}
Major cultural death celebrations such as Mexico's Day of the Dead, Halloween, and All Saint's Day in many Christian countries, all involve the remembrance of the ancestral dead in various aspects. Holiday celebrations can differ in purpose. Some focus on recommitment - aiding in socialization of society's members, social integration, and reaffi rming commitment to values. Others serve as tension management holidays, enabling celebrants to "let off steam" or "let loose." Tension management holidays only indirectly enforce shared beliefs by offering the occasional release from conformity and behavioral norms of society (Etzioni and Bloom 2004; Durkheim 1965). Studying holidays as cultural products offers a unique perspective of society's cultural values and enhances our understanding of consumer interpretation of foreign consumption rituals.
\end{abstract}

Albinsson, Pia A., Marco Wolf, G. David Shows, and Karen M. Hood (2016), "Cultural Appropriation of the Death Celebrations: The Case of Halloween," in Let's Get Engaged! Crossing the Threshold of Marketing's Engagement Era, Developments in Marketing Science: Proceedings of the Academy of Marketing Science, (C) Academy of Marketing Science 2016 M.W. Obal et al. (eds.) DOI 10.1007/978-3-319-11815-4_227. Publisher version of record available at: https://www.researchgate.net/ publication/300130371_Cultural_Appropriation_of_Death_Celebrations_The_Case_of_Halloween 


\title{
Cultural Appropriation of Death Celebrations: The Case of Halloween
}

\author{
Pia A. Albinsson, Marco Wolf, G. David Shows, and Karen M. Hood
}

\begin{abstract}
Major cultural death celebrations such as Mexico's Day of the Dead, Halloween, and All Saint's Day in many Christian countries, all involve the remembrance of the ancestral dead in various aspects. Holiday celebrations can differ in purpose. Some focus on recommitment - aiding in socialization of society's members, social integration, and reaffirming commitment to values. Others serve as tension management holidays, enabling celebrants to "let off steam" or "let loose." Tension management holidays only indirectly enforce shared beliefs by offering the occasional release from conformity and behavioral norms of society (Etzioni and Bloom 2004; Durkheim 1965). Studying holidays as cultural products offers a unique perspective of society's cultural values and enhances our understanding of consumer interpretation of foreign consumption rituals.

Researchers have explored Halloween as a consumption ritual (Belk 1990; Levinson et al. 1992) with both carnivalesque (Belk 1994) and community building properties (Harris 2006; McKechnie and Tynan 2008). We find that newly adopted Halloween rituals are an under-researched consumption phenomenon, especially within the global context. One exception is McKechnie and Tynan's (2008) study on British consumers' celebrations. We respond to their call for further investigation on the diffusion of North American Halloween celebrations by conducting a qualitative study of Swedish Halloween celebrations. In doing so, we seek a deeper understanding of consumer perceptions of foreign celebrations, and the dimensions of their readiness to adopt unfamiliar practices. Through qualitative research methods including in-depth interviews, participant observations and open-ended questionnaires we seek to answer the following: Why is death celebrated?
\end{abstract}

\author{
P.A. Albinsson $(\varangle) \bullet$ G.D. Shows \\ AppalachianStateUni versity, Boone, NC, USA \\ e-mail: albinssonpa@appstate.edu; showsgd@appstate.edu \\ M. Wolf \\ SouthernMississippiUni versity, Hattiesburg, MS, USA \\ e-mail: marco.wolf@usm.edu \\ K.M. Hood \\ EasternKentuckyUniversity , Richmond, KY, USA \\ e-mail: karenhood@eku.edu
}


What fascinates consumers to dress up as "dead" or "dark" figures? What motivates Swedes to adopt yet another holiday? During the 2012 and 2013 fall seasons, we collected two rounds of open-ended questionnaires from High School students (96 in total), in-depth interviews with families (adults and children) and participant observation at Halloween themed resorts, trick or treating events and Halloween parties (children/family oriented). The data analysis entailed thematic coding through individual iterative hermeneutic analysis (Thompson 1997). In our findings we discuss four emergent themes: Embracing versus Resisting, Identity Play, Media and Retail Facilitation of Ritual Adoption, and Protecting Kids.

Global market participants often interpret and modify cultural practices and meanings to match their local backgrounds (Bennet 1999; Klitgaard Poulsen 1996). Based on extant research and this study's findings it is clear that many consumers edit and engineer certain aspects of rituals to fit their needs (Etzioni 2004). Given the increasing popularity and growth of Halloween, our insights contribute to the literature by extending previous work on the mechanisms of adapting foreign culture celebrations (Kimura and Belk 2005) and add to the understanding that celebrating foreign holidays goes beyond national appropriation i.e. Americanization (Etzioni and Bloom 2004; Etzioni 2004).

Keywords Consumption Ritual • Holiday Celebrations • Death Celebrations • Halloween

\section{References}

References Available Upon Request 